\title{
Nursing Diagnostics of Nutrition Domain of NANDA International in Hemodialysis Patients
}

\author{
Érida Maria Diniz Leite ${ }^{1}$, Sama Mikaella de Oliveira², \\ Maria Isabel da Conceição Dias Fernandes², Maria das Graças Mariano Nunes², \\ Cyndi Fernandes de Lima² ${ }^{2}$ Ana Luisa Brandão de Carvalho Lira ${ }^{2}$ \\ ${ }^{1}$ Department of Nursing, Hospital Academic Onofre Lopes, Natal, Brasil \\ ${ }^{2}$ Department of Nursing, University of Rio Grande do Norte, Natal, Brasil \\ Email: bebel_6@hotmail.com
}

Received 2 February 2016; accepted 14 March 2016; published 17 March 2016

Copyright (C) 2016 by authors and Scientific Research Publishing Inc.

This work is licensed under the Creative Commons Attribution International License (CC BY). http://creativecommons.org/licenses/by/4.0/

(c) (i) Open Access

\section{Abstract}

Introduction: The dialysis causes the loss of the nutrients and the elevation of catabolism, thus, patients in dialysis have at high risk for the loss of body reserves of protein and energy. Objective: To identify nursing diagnoses of nutrition domain of NANDA International in hemodialysis patients and to correlate them to the socioeconomic and clinical data. Design: Cross-sectional study. Setting: Performed in a large university hospital in northeastern Brazil. Participants: The first stage was carried out with 50 patients, selected with the following inclusion criteria: Being hospitalized and undergoing hemodialysis in that hospital; aged 18 years old or over; being conscious and oriented. Exclusion criteria were patients undergoing hemodialysis in that hospital with external service, pregnant women and patients being treated by plasmapheresis. In the second stage, participants were three nursing specialists in nephrology and nursing diagnoses. Methods: The defining characteristics of the nursing diagnoses inserted in the nutrition domain were observed in patients and then these data were judged by nurses, in order to identify diagnoses present in each patient. The Chi-square, Fisher's exact and Mann-Whitney tests were used in the analysis of the relationship of socioeconomic and clinical data, with an adopted $p$ value of $<0.05$. Results: The study identified six diagnoses of nutrition domain with prevalence $\geq 50 \%$ in patients. Among these, the diagnosis: Risk for impaired liver function, imbalanced nutrition: More than body requirements, risk for deficient fluid volume, readiness for enhanced fluid volume were significantly associated with gender $(p=0.001)$, origin $(p=0.014)$, religion $(p=0.046)$ and income $(p=0.039)$, respectively. Conclusion: The variables that showed significant association were risk of impaired liver function and gender; imbalanced nutrition: More than body requirements and origin requirements; risk for deficient fluid volume and religion; and deficient fluid volume and income. 


\section{Keywords}

\section{Nursing, Nursing Diagnosis, Risk Groups Nutrition, Renal Dialysis}

\section{Introduction}

The kidneys are responsible for removing harmful substances for the proper functioning of the body, reabsorbing vital nutrients, regulating the volume of fluid and electrolytes, and producing hormones [1]-[3]. However, when the kidneys become unable to perform these functions, the patient develops renal failure, resulting in body damage, such as fluid retention, electrolyte abnormalities and accumulation of toxic substances [3]. Thus, Chronic Kidney Disease (CKD) is the slow and progressive decline in renal function, causing the accumulation of metabolic waste products in the blood [4].

The need for renal replacement therapy is required when the glomerular filtration rate has a value less than 15 $\mathrm{ml} / \mathrm{minute} / 1.73 \mathrm{~m}^{2}$ [2]. In Brazil, most people with CKD undergo outpatient hemodialysis (HD), with sessions on average three times a week and lasting three to four hours [5]. The HD is the blood's exposure of patient to extracorporeal circulation, moving through a semipermeable membrane, known as capillary dialyzer filter. The filtered blood is then returned to the patient free of excess fluids and metabolic products derived [4] [6] [7]. Thus, the HD aims to compensate for renal dysfunction through depuration of blood by removing excess fluid and metabolites [8].

The 2013 dialysis census showed that over time there has been an increase in population on dialysis, with 100,397 patients only in 2013, which was an increase of $2.8 \%$ over the year 2012, and $89.7 \%$ performed hemodialysis (HD). In addition, it was observed that the age group between 19 and 64 years old was the most affected [5].

The realization of HD led to several changes in the daily lives of patients with CKD and their families, requiring adaptation to treatment. Among the changes are highlighted food and water restrictions and limitations directed to professional activities, physical and leisure, that is why are identified feelings of revolt in these patients, as well as depressive symptoms and impotence. Thus the hemodialysis treatment, is revealed as a factor limiting the quality of life of these patients, however, in contrast, this treatment provides an improvement in their conditions of life/health. Thus, most patients evaluate the achievement of the dialysis treatment as satisfactory [9] [10].

Although prolonging the life of the patient, HD can trigger hemodynamic and nutritional complications, because during this treatment not only undesirable substances are removed, such as urea, but also important substances for the body such as amino acids, peptides, vitamins and glucose [7] [8] [11]. Besides the loss of these nutrients, the elevation of catabolism occurs during HD. Thus, the HD patients are at high risk for the loss of body reserves of protein and energy [11].

The index of morbidity and mortality is associated with nutritional status and adequacy of dialysis [8] [12]. It is stated that these rates are extremely high [13], highlighting mortality with a fee $48 \%$ [14].

In this context, the nurse is one of the agents involved in direct assistance to this population, performing an indispensable role, through the planning and provision of care, in order to prevent complications, reduce anxiety and stress [15].

Thus, the nurse is able to identify the needs of each client and prescribe a qualified and effective care through the steps of the nursing process (NP) [16] [17]. The NP stage is responsible for identifying the altered human response, called Nursing Diagnosis (ND). The ND should be identified based on taxonomy, and the most known taxonomy is the North American Nursing Association (NANDA International), composed of thirteen domains [18].

Among these, there is the nutrition domain of NANDA International in the context of patients undergoing HD [19]-[22]. Diagnostics for the intake, metabolism and hydration are included in this domain [18]. In most studies on the subject, the focus is mainly on those issues related to hydration [19]-[22]. However, problems related to overweight and malnutrition are also present and are considered relevant by its repercussions [23].

The occurrence of certain nursing problems in this clientele usually comes from different life contexts in which they live, as well as from the existing clinical variability. Malnutrition, for example, is related to depres- 
sion, monthly personal income, source of income, age and low level of education [24]. Thus, the relationships between the socioeconomic or clinical variables and the nursing diagnoses help nursing professionals to focus on the best care to be provided.

Thus, in view of the above, the authors became interested in developing a study that would help the nurse in identifying problems entered into the nutrition domain present in the patient on hemodialysis linked to their socioeconomic and clinical context, given the importance of promoting safe, resolute care and supported in their own scientific knowledge. Thus, the aim of the study was to identify the nutrition domain of nursing diagnoses of NANDA International in patients undergoing hemodialysis (HD) and correlate them to the socioeconomic and clinical data.

\section{Method}

\subsection{Design and Setting}

Cross-sectional study conducted in a large teaching hospital in northeastern Brazil.

\subsection{Sample Calculation and Sample}

The population consisted of 210 patients, from January 2012 to January 2013. The sample was calculated based on the formula for finite populations, considering a confidence level of $95 \%$, sample error of $12 \%$ and a conservative value for the prevalence of patients with nursing diagnoses of $50 \%$. From this, it was identified a sample of 50 patients.

\subsection{Sample Selection}

Sampling was chosen by convenience of consecutive type, with the following inclusion criteria: being hospitalized and undergoing hemodialysis in that hospital; aged 18 years old or over; being conscious and oriented. Exclusion criteria were patients undergoing hemodialysis in that hospital with external service, pregnant women and patients being treated with plasmapheresis.

\subsection{Data Collection and Instrument}

Data collection took place from December 2013 to May 2014 during HD sessions, and was held by the researcher and four undergraduate research scholars. The collectors received six hours of training, divided into two stages: 1) lecture on the subject of study, objectives, methodology and the ND of the nutrition domain of NANDA International [25]; 2) detailed discussion of instrument and practice of physical examination.

The collection instrument was a form of history and physical examination, which was adapted from a study of nursing diagnoses in patients undergoing hemodialysis [26]. It is noteworthy that the appearance of the instrument was validated by two specialist nurses in nursing diagnoses and/or nephrology, belonging to the research group Relief and Epidemiology Practices in Health and Nursing (PAESE) of the Federal University of northeastern Brazil.

It is noteworthy that among the diagnoses that make up the nutrition domain, four were not addressed in the collection instrument, because of the profile of the studied clientele. Diagnoses were: insufficient breast milk, ineffective infant feeding pattern, neonatal jaundice and risk for neonatal jaundice.

The collected data were grouped into 50 worksheets in Microsoft Excel 2010 Officer for each patient, containing, in each of these, defining characteristics, related factors and risk related to 13 diagnoses.

\subsection{Diagnostic Inference}

Subsequently, the 50 worksheets were sent to specialist nurses in nursing diagnoses and/or nephrology, in order to judge the presence or absence of the 13 diagnoses in the studied clientele from the previously reported clinical indicators.

Six experts were intentionally invited to participate in the study. They underwent training, and then an evaluation of the diagnostic capacity. At that time, 12 fictitious case histories were randomly distributed to participants, who responded the clinical cases three times each, at different times, totaling 36 evaluations.

Finally, to verify the performance of experts as diagnosticians, it was applied the Kappa test to check the level 
of agreement of these in relation to the assessed diagnoses, and then three specialists were selected after application of the test for diagnostic inference. Kappa is an index designed to measure only the correlation between pairs. So, three diagnosticians were selected, those who obtained almost perfect agreement $(0.80-1.00)$.

Therefore, to obtain only the responses of experts, these were compared and. in case of disagreement, it was applied the rule of the majority, considering the diagnosis present when two of the three diagnosticians identified it as present. This inference occurred in the period from July to August 2014.

\subsection{Data Analysis}

For analysis of socioeconomic and clinical data, the descriptive statistics was applied and the relative and absolute frequencies, mean, standard deviation, median, maximum and minimum were evaluated. The KolmogorovSmirnov test was also applied, in order to verify the normality of the data $(p<0.05)$. To analyze the statistical association between Chi-square, Fisher's exact and Mann-Whitney tests were used, and it was adopted $p$ value $<$ 0.05 .

\subsection{Ethics Approval}

The research project was approved by the Research Ethics Committee of the institution responsible for the research, with opinion number 392,535 and Certificate of Presentation for Ethical Consideration number 18710613.4.00005537. It is noteworthy that patients and specialists were consulted about their interest in participating in the research and informed about the study objectives, methodological procedures, risks, making them aware of confidentiality given to information and identities. So those who expressed interest, was made the request to give consent of the study, by reading and subsequent signing of the Terms of Informed Consent.

\section{Results}

Most patients interviewed were female (62\%), had a partner (54\%), had some religion (80\%), came from the country towns (76\%) and underwent the classic hemodialysis type (92\%). Regarding age, the average was 47.5 years old ( \pm 14.61$)$, with a minimum of 19 and maximum of 80 . With respect to years of study, there was a median of five years. The income showed a median of 1.5 minimum salaries. Concerning hemodialysis data, $86 \%$ of patients had a diagnosis of CKD, with a median of 27 months of diagnosis, 10.5 months of HD and 4 hours of dialysis duration.

Concerning the prevalence of nursing diagnoses of nutrition domain, the risk for electrolyte imbalance was present in $100 \%(\mathrm{n}=50)$ of patients, the risk for unstable blood glucose level and excess fluid volume was present in $90 \%(n=45)$ readiness for enhanced fluid balance in $86 \%(n=43)$, readiness for enhanced nutrition in $80 \%(n=40)$, the risk for deficient fluid volume in $76 \%(n=43)$, impaired swallowing in $50 \%(n=25)$ risk for imbalanced fluid volume by $44 \%(n=22)$, imbalanced nutrition: more than body requirements in $38 \%(n=$ 19), risk for impaired liver function in $34 \%(n=17)$, imbalanced nutrition: less than body requirements in $32 \%$ $(\mathrm{n}=16)$, risk for imbalanced nutrition: more than body requirements in $22 \%(\mathrm{n}=11)$ and deficient fluid volume in $2 \%(n=1)$.

Regarding the association between the socioeconomic and clinical variables and the nursing diagnoses of the nutrition domain of NANDA International, imbalanced nutrition: more than body requirements was significantly associated with the variable origin $(p=0.014)$, being prevalent in patients from country towns. Diagnosis risk for impaired liver function was associated with gender $(p=0.001)$ and showed prevalence for males. Risk for deficient fluid volume had significant association with religion $(p=0.046)$, being mostly associated to individuals practicing some religion. Finally, readiness for enhanced fluid volume and family income $(p=0.039)$ showed a statistically significant association, with an income of 1.5 minimum wage, as shown in Table 1.

\section{Discussion}

Concerning the socioeconomic characterization, the study found that most HD patients were female, aged between 19 and 80 years old, had a partner, came from the country towns, had some religion, most were retired or received pension and had few years of study, with a median of five years. This data corroborate the results of research addressing a similar theme [18]. 
Table 1. Distribution of association between the nursing diagnoses of nutrition domain of NANDA International and the socioeconomic and clinical variables of hemodialysis patients. Natal/RN, 2016.

\begin{tabular}{|c|c|c|c|c|c|c|c|c|c|c|c|}
\hline Nursing diagnoses & Age & $\begin{array}{l}\text { Years } \\
\text { of study }\end{array}$ & $\begin{array}{l}\text { Family } \\
\text { income }\end{array}$ & $\begin{array}{l}\text { Time } \\
\text { of RD }\end{array}$ & $\begin{array}{l}\text { Time } \\
\text { of } \mathrm{HD}\end{array}$ & $\begin{array}{l}\text { Duration } \\
\text { of } \mathrm{HD}\end{array}$ & $\begin{array}{l}\text { Type } \\
\text { of HD }\end{array}$ & Gender & $\begin{array}{l}\text { Marital } \\
\text { status }\end{array}$ & Religion & Origin \\
\hline Impaired swallowing & $0.351^{1}$ & $0.159^{1}$ & $0.194^{1}$ & $0.712^{1}$ & $0.518^{1}$ & $0.728^{1}$ & $0.695^{2}$ & $0.382^{3}$ & $0.156^{3}$ & $1.000^{3}$ & $0.508^{3}$ \\
\hline $\begin{array}{l}\text { Imbalanced nutrition: } \\
\text { more than body requirements }\end{array}$ & $0.617^{1}$ & $0.770^{1}$ & $0.950^{1}$ & $0.881^{1}$ & $0.846^{1}$ & $0.085^{1}$ & $0.507^{2}$ & $0.895^{3}$ & $0.879^{3}$ & $0.579^{2}$ & $0.014^{2}$ \\
\hline $\begin{array}{l}\text { Risk for imbalanced nutrition: } \\
\text { more than body requirements }\end{array}$ & $0.052^{1}$ & $0.376^{1}$ & $0.190^{1}$ & $0.972^{1}$ & $0.614^{1}$ & $0.050^{1}$ & $0.357^{2}$ & $0.405^{2}$ & $0.967^{3}$ & $0.618^{2}$ & $0.472^{2}$ \\
\hline $\begin{array}{l}\text { Imbalanced nutrition: } \\
\text { less than body requirements }\end{array}$ & $0.700^{1}$ & $0.183^{1}$ & $0.896^{1}$ & $0.909^{1}$ & $0.798^{1}$ & $0.818^{1}$ & $0.091^{2}$ & $0.566^{3}$ & $0.697^{3}$ & $0.400^{2}$ & $0.120^{2}$ \\
\hline Readiness for enhanced nutrition & $0.818^{1}$ & $0.353^{1}$ & $0.341^{1}$ & $0.349^{1}$ & $0.136^{1}$ & $0.880^{1}$ & $0.397^{2}$ & $0.173^{2}$ & $0.089^{2}$ & $0.349^{2}$ & $0.551^{2}$ \\
\hline Risk for impaired liver function & $0.424^{1}$ & $0.992^{1}$ & 0.600 & 0.276 & 0.228 & 0.799 & $0.420^{2}$ & $0.001^{3}$ & $0.276^{3}$ & $0.461^{2}$ & $0.350^{2}$ \\
\hline $\begin{array}{l}\text { Risk for unstable } \\
\text { blood glucose level }\end{array}$ & $0.706^{1}$ & $0.087^{1}$ & $0.327^{1}$ & $0.115^{1}$ & $0.296^{1}$ & $0.394^{1}$ & $0.647^{2}$ & $0.355^{2}$ & $0.578^{2}$ & $0.311^{2}$ & $0.237^{2}$ \\
\hline Risk for electrolyte imbalance & - & - & - & - & - & - & - & - & - & - & - \\
\hline $\begin{array}{c}\text { Readiness for } \\
\text { enhanced fluid balance }\end{array}$ & $0.891^{1}$ & $0.510^{1}$ & $0.039^{1}$ & $0.848^{1}$ & $0.827^{1}$ & $0.827^{1}$ & $0.536^{2}$ & $0.166^{2}$ & $0.407^{2}$ & $0.187^{2}$ & $0.126^{2}$ \\
\hline Deficient fluid volume & $0.840^{1}$ & $0.360^{1}$ & $0.240^{1}$ & $0.880^{1}$ & $0.840^{1}$ & $0.800^{1}$ & $0.920^{2}$ & $0.620^{2}$ & $0.540^{2}$ & $0.800^{2}$ & $0.760^{2}$ \\
\hline Risk for deficient fluid volume & $0.601^{1}$ & $0.775^{1}$ & $0.962^{1}$ & $0.155^{1}$ & $0.370^{1}$ & $0.500^{1}$ & $0.679^{2}$ & $0.238^{2}$ & $0.094^{3}$ & $0.046^{2}$ & $0.306^{2}$ \\
\hline Excess fluid volume & $0.267^{1}$ & $0.159^{1}$ & $0.488^{1}$ & $0.683^{1}$ & $0.851^{1}$ & $0.394^{1}$ & $0.647^{2}$ & $0.638^{2}$ & $0.229^{2}$ & $0.311^{2}$ & $0.655^{2}$ \\
\hline Risk for imbalanced fluid volume & $0.639^{1}$ & $0.485^{1}$ & $0.581^{1}$ & $0.468^{1}$ & $0.535^{1}$ & $0.882^{1}$ & $0.598^{2}$ & $0.121^{3}$ & $0.522^{3}$ & $0.216^{2}$ & $0.393^{2}$ \\
\hline
\end{tabular}

${ }^{1}$ Mann-Whitney U test; ${ }^{2}$ Fisher's exact test; ${ }^{3}$ Chi-square test.

On the income, the study reveals that this is directly related to the clinical treatment of the patient. Thus, patients with monthly personal income below one minimum wage are more likely to develop malnutrition, and are 1.5 to 4.2 more likely to have this diagnosis than those who earn more than one minimum wage. In terms of occupation, the retired patients are 1.3 to 5.9 more likely to acquire malnutrition than those who had other sources as main income. And finally, regarding education, illiterates were more likely to develop malnutrition compared those with complete/incomplete higher education [24].

The percentage of malnourished patients in the final stages of the disease is between $40 \%$ and $70 \%$ according to a study on the topic [27]. The percentage of this problem was identified in a smaller amount, $32 \%$ in this study. This variation is due to the use of different methods used for nutritional assessment and population characteristics, being related, among others, loss of appetite, dysgeusia, impaired digestion and absorption, metabolic acidosis and emotional stress [27].

Malnutrition can also be explained by considering the hemodialysis treatment, where smaller molecules like urea, glucose, sodium and potassium, present in the blood pass through the membrane of the dialyser is removed, larger molecules also are removed, substances essential to the body, and amino acids, peptides and vitamins [7] [8].

Thus, the HD procedure interferes with protein metabolism by loss of amino acids from 6 to 12 grams per hemodialysis, which comes to be reduced between 20\% and 50\% after each HD [28]. Low albumin levels are associated with increased mortality for patients on hemodialysis. Thus, dietary changes to promote greater protein intake to improve the nutritional status of these patients should be suggested [29].

Are also lost glucose molecules whose molecular weight is too small, facilitating your displacement of the membrane of capillary [30]. These losses can vary from 15grams to 30 grams of glucose per hemodialysis, which entails energy loss, as evidenced per episodes of hypoglycemia [31] [32]. To control hypoglycemia are needed as nursing measures: monitor blood glucose levels and provide simple carbohydrates at the time of dialysis [33].

The risk for unstable blood glucose level was present in $90 \%$ of the sample. Thus, a study on complications during dialysis showed a frequency of $62.37 \%$ of hypoglycemia compared to other complications [31]. In contrast, a survey showed a low rate for this diagnosis: only $9 \%$ of patients had risk for unstable blood glucose level 
[34]. However, despite the low prevalence of association between diabetes and hypoglycemia in some studies, it is important to consider it because of the large number of hemodialysis patients with diabetes.

Furthermore, research shows that many of these individuals are sedentary [35], which contributes to the increase in obesity, factors directly related to insulin resistance, thereby contributing to the onset of this nursing diagnosis in the patients studied, which have a greater tendency to changes in blood glucose level [36].

Added to this, are highlights the feelings of loss, frustration and limitations of treatment and disease that are related to mental and emotional aspects. The burden of treatment may be expressed by feelings of worthlessness, devaluation and depression evidenced by impairment of quality of life of these patients [37]. Thus, renal failure patients on hemodialysis experience psychological stress situations that may affect the blood glucose levels. This perspective, the nurse must be alert to stressful situations experienced by these patients, as well as monitoring of blood glucose levels [31].

The diagnosis of risk for electrolyte imbalance was present in $100 \%$ of patients in this study and therefore it was not possible to apply statistical tests. Similar result was identified in a survey conducted in HD units in Belo Horizonte [34]. In this respect, it is observed that the kidney patient commonly has glomerular, tubular and endocrine functions of kidneys impaired. These organs do not perform effectively blood filtration, triggering an imbalance in electrolytes rate [1]. Thus, it is assumed that these patients have a higher risk for the development of electrolyte imbalance.

In this context, effective measures are needed performed by the nurses for the control of electrolytes, especially sodium, in these individuals. In study about the self-care measures undertaken by HD patients to manage restrictions of sodium and fluids in the diet, indicates as main measures: Avoid instant products and Asian food, do not put salt on the table, reduction of salt the food cooking, to avoid foods with very salt [38].

The excess fluid volume was prevalent in most of the studied clientele, corroborating study on the prevalence of this diagnosis with similar clientele, which showed an $82 \%$ rate. That research also highlighted as main clinical symptoms linked to this diagnosis: edema, weight gain, pulmonary congestion and abnormal breath sounds [19]. For this nursing problem the following nursing activities must be performed: monitor the intake and output of fluids, checking vital signs and to weight the pacient before and after hemodialysis [33].

The presence of the nursing diagnoses readiness for enhanced fluid balance and readiness for enhanced nutrition, which had prevalence of $86 \%$ and $80 \%$, respectively, can be directly related to the guidelines provided by health professionals to these patients. A survey conducted in 12 dialysis clinics noted that all guidance provided to patients were directed to the water and nutrient restriction, and that $49.9 \%$ of subjects reported following these recommendations [24]. In this context, educational activities performed by nurses are essential for the patient to understand their health-disease process and consequently have a good acceptance and adherence to treatment [39].

The risk for deficient fluid volume had a percentage of $76 \%$, but, in the literature, nothing was found to justify the presence of this diagnosis. Thus, its high prevalence may be related to the presence of risk factors such as deficiency of knowledge, failure of regulatory mechanisms and fluid loss by abnormal pathways [25]. Among the nursing activities that can be applied to this diagnosis are: monitoring the intake and output of fluids, monitor water loss, check vital signs, measure weight, position the patient in the Trendelenburg position when hypotension, and guide the patient and/or family on measures for the treatment of hypovolemia [33].

Thus, with regard to diagnoses identified in this study with frequencies greater than $50 \%$, they were found in studies with similar population [22] [34] [40].

In this study, we could also see some significant statistical associations. One of those was between the ND risk for impaired liver function and gender, in which male was dominant in this clientele. In this aspect, a crosssectional study conducted in an Occupational Health Care Service at a public university found that males had the highest rates for the standard group of risk and harmful alcohol consumption and probable alcohol dependence, with a percentage of $65.9 \% \%$ [41]. This may have contributed to the emergence of this diagnosis.

Another association occurs between the ND imbalanced nutrition: More than body requirements and the variable origin, in which most individuals come from country towns. This association may be related to the cultural issue, since these individuals usually have higher calorie eating habits and have little access to information about appropriate diet. In addition, a study indicated that this ND is linked to physical inactivity and poor eating habits. It is the nurse's role to guide the patient regarding diet according to the possibilities and customs of each patient [42].

For this problem of nursing, nursing interventions listed are: control of eating disorders, performing the fol- 
lowing activities: consult a nutritionist to determine daily caloric intake required to achieve and/or maintain ideal weight, teach and reinforce patient information on good nutrition, to monitoring of daily intake of highcalorie foods, offer support to the patient as part of new eating habits and monitor the patient's weight routine. Another positive intervention for weight loss would be do exercises, with the following activities: encourage the person to get exercise, assist the patient to establish short and long term goals for your exercise program, report on the health benefits and physiological effects of exercise, counseling on the frequency, duration and intensity of exercise and monitor patient compliance [33].

Regarding the diagnosis risk for deficient fluid volume, this was associated with religion, and most of the individuals had some religion. Study claims that religion is an important issue for the health of hemodialysis patient, because it is related to increased quality of life and better coping with the disease [43].

Finally, there was association between readiness for enhanced fluid balance and family income, but it was not found in the literature any justification for such an association.

Given the above, it is up to the nurse to remain attentive to the clinical indicators of this population and their relationship with socioeconomic and clinical factors, in order to solve health problems, especially with regard to nutritional changes involving this clientele.

\section{Conclusions}

This study identified the diagnoses of the domain nutrition of NANDA International with higher prevalence in patients undergoing hemodialysis, namely: Risk for electrolyte imbalance, risk for unstable blood glucose level, excess fluid volume, readiness for enhanced fluid balance, readiness for enhanced nutrition and risk for deficient fluid volume.

It is noteworthy that the ND: Risk for impaired liver function, imbalanced nutrition: More than body requirements, risk for deficient fluid volume, and readiness for enhanced fluid balance were significantly associated with gender, origin, religion and income respectively.

From the above, it is evident that there is a high prevalence of this domain in patients undergoing hemodialysis, and that a relationship exists between these diagnoses and the socioeconomic and clinical variables. Therefore, it is imperative that nurses recognize these problems in their social and clinical context, with a view to elucidating them efficiently.

Thus, the conduction of studies that deal with the identification of specific nursing diagnoses for certain clientele favors the decision making performed by nurses in clinical practice, so that the diagnostic inference is fast and accurate front to the individual's needs.

This study was limited by the shortage of studies on the nutrition domain and HD patients. Thus, it is suggested the development of more studies on this domain of NANDA International, keeping in view the importance and impact of nursing diagnoses included in this domain.

\section{References}

[1] Bastos, M.G., Bregman, R. and Kirsztajn, G.M. (2010) Doença renal crônica: Frequente e grave, mas também prevenível e tratável. Revista Associação Médica Brasileira, 56, 248-253. http://dx.doi.org/10.1590/S0104-42302010000200028

[2] National Kidney Foundation (2013) KDIGO, Kidney Disease Improving Global Outcomes: Clinical Practice Guideline for the Evaluation and Management of Chronic Kidney Disease. American Journal of Kidney Diseases, 3, 1-24.

[3] Zatz, R., Seguro, A.C. and Malnic, G. (2011) Bases fisiológicas da nefrologia. Atheneu, São Paulo.

[4] Riella, M.C. (2010) Princípios de nefrologia e distúrbios hidroeletrolíticos. 5th Edition, Guanabara Koogan, São Paulo.

[5] Sociedade Brasileira de Nefrologia (SBN) (2014) Censo de Diálise 2013. São Paulo. http://www.sbn.org.br/pdf/censo_2013-14-05.pdf

[6] Fermi, M.R.V. (2011) Manual de Diálise para Enfermagem. 2nd Edition, Medsi, Rio de Janeiro.

[7] Reddenna, L., Basha, S.A. and Reddy, K.S.K. (2014) Dialysis Treatment: A Comprehensive Description. International Journal of Pharmaceutical Sciences Review and Research, 3, 1-13.

[8] Riella, M.C. and Martins, C. (2013) Nutrição e o Rim. 2nd Edition, Guanabara Koogan, Rio de Janeiro.

[9] Rudnicki, T. (2014) Doença renal crônica: Vivência do paciente em tratamento de hemodiálise. Contextos Clínicos, 7, 105-116. http://dx.doi.org/10.4013/ctc.2014.71.10 
[10] Silva, A.S., Silveira, R.S., Fernandes, G.F.M., Lunardi, V.L. and Backes, V.M.S. (2011) Percepções e mudanças na qualidade de vida de pacientes submetidos à hemodiálise. Revista Brasileira de Enfermagem, 64, 839-844. http://dx.doi.org/10.1590/S0034-71672011000500006

[11] Associação Médica Brasileira: Conselho Federal de Medicina (2011) Projeto diretrizes para terapia nutricional para pacientes em hemodiálise crônica. São Paulo.

[12] Li, T., Liu, J., An, S., Dai, Y. and Yu, Q. (2014) Body Mass Index and Mortality in Patients on Maintenance Hemodialysis: A Meta-Analysis. International Urology and Nephrology, 46, 623-631. http://dx.doi.org/10.1007/s11255-014-0653-x

[13] Jablonski, K.L. and Chonchol, M. (2014) Recent Advances in the Management of Hemodialysis Patients: A Focus on Cardiovascular Disease. F1000Prime Reports, 6, 1-10.

[14] Siviero, P.C.L., Machado, C.J. and Cherchiglia, M.L. (2014) Insuficiência renal crônica no Brasil segundo enfoque de causas múltiplas de morte. Caderno de Saúde Coletiva, 22, 75-85. http://dx.doi.org/10.1590/1414-462X201400010012

[15] Smeltzer, S.C. and Bare, B.G. (2011) Brunner \& Suddarth: Tratado de Enfermagem Médico-Cirúrgica. 12th Edition, Guanabara Koogan, Rio de Janeiro.

[16] Frazão, C.M.F.Q., Ramos, V.P. and Lira, A.L.B.C. (2011) Qualidade de vida de pacientes submetidos à hemodiálise. Revista Enfermagem UERJ, 19, 577-582.

[17] Silva, E.G.C., Oliveira, V.C., Neves, G.B.C. and Guimarães, T.M.R. (2011) El conhecimento do enfermeiro sobre a Sistematização da Assistência de Enfermagem: da teoria à prática. Revista da Escola de Enfermagem da USP, 45, 1380-1386. http://dx.doi.org/10.1590/S0080-62342011000600015

[18] Herdman, T.H. and Kamitsuru, S. (2014) NANDA International Nursing Diagnoses: Definitions \& Clasification, 2015-2017. 10th Edition, Wiley Blackwell, Oxford.

[19] Fernandes, M.I.C.D., Medeiros, A.B.A., Macedo, B.M., Vitorino, A.B.F., Lopes, M.V.O. and Lira, A.L.B.C. (2014) Prevalência do diagnóstico de enfermagem Volume de líquidos excessivo em pacientes submetidos à hemodiálise. Revista da Escola de Enfermagem da USP, 48, 446-453. http://dx.doi.org/10.1590/S0080-623420140000300009

[20] Frazão, C.M.F.Q., Medeiros, A.B.A., Silva, F.B.B.L., Sá, J.D. and Lira, A.L.B.C. (2014) Diagnósticos de enfermagem em pacientes renais crônicos em hemodiálise. Acta Paulista de Enfermagem, 27, 40-43. http://dx.doi.org/10.1590/1982-0194201400009

[21] Poveda, V.B., Alves, J.S., Santos, E.F. and Moreira, A.G.E. (2014) Diagnósticos de enfermagem em pacientes submetidos à hemodiálise. Enfermería Global, 34, 70-81.

[22] Dallé, J. and Lucena, A.F. (2012) Diagnósticos de enfermagem identificados em pacientes hospitalizados durante sessões de hemodiálise. Acta Paulista de Enfermagem, 25, 504-510. http://dx.doi.org/10.1590/S0103-21002012000400004

[23] Stefanelli, C., Andreoti, F.D., Quesada, K.R. and Detregiachi, C.R.P. (2010) Avaliação nutricional de pacientes em hemodiálise. Journal of the Health Sciences Institute, 28, 268-267.

[24] Oliveira, G.T.C., Andrade, E.I.G., Acurcio, F.A., Cherchiglia, M.L. and Correia, M.I.T.D. (2011) Avaliação nutricional de pacientes submetidos à hemodiálise em centros de Belo Horizonte. Revista da Associação Médica Brasileira, 58, 240-247. http://dx.doi.org/10.1590/S0104-42302012000200022

[25] Herdman, T.H. (2013) Diagnósticos de Enfermagem da NANDA: Definições e classificação—2012/2014. 2nd Edition, Artmed, Porto Alegre.

[26] Frazão, C.M.F.Q. (2012) Diagnósticos de enfermagem em pacientes submetidos à hemodiálise: Semelhanças entre o Modelo de Adaptação e a NANDA Internacional. Dissertação, Universidade Federal do Rio Grande do Norte, Natal.

[27] Sahay, M., Sahay, R. and Baruah, M.P. (2014) Nutrition in Chronic Kidney Disease. Journal of Medical Nutrition and Nutraceuticals, 3, 11-18. http://dx.doi.org/10.4103/2278-019X.123437

[28] Garibotto, G., Sofia, A., Saffioti, S., Bonanni, A., Mannucci, I. and Verzola, D. (2010) Amino Acid and Protein Metabolism in the Human Kidney and in Patients with Chronic Kidney Disease. Clinical Nutrition, 29, 424-433. http://dx.doi.org/10.1016/j.clnu.2010.02.005

[29] Lukawsky, L.R., Kheifets, L., Arah, O.A., Nissenson, A.R. and Kalantar-Zadeh, K. (2014) Nutritional Predictors of Early Mortality in Incident Hemodialysis Patients. International Urology and Nephrology, 46, 129-140. http://dx.doi.org/10.1007/s11255-013-0459-2

[30] Abe, M., Okada, K., Ikeda, K., Matsumoto, S., Soma, M. and Matsumoto, K. (2011) Characterization of Insulin Adsorption Behavior of Dialyzer Membranes Used in Hemodialysis. Artificial Organs, 35, 398-403. http://dx.doi.org/10.1111/j.1525-1594.2010.01112.x

[31] Leite, E.M.D., Araújo, A.R.A., Lira, A.L.B.C., Fernando, S.F.S., Oliveira, A.C.F. and Lima, C.F. (2013) Perfil clínico de pacientes submetidos à hemodiálise. Paraninfo Digital, 19, 1-8. 
[32] Pedersen, E.B., Ardal, B., Bech, J.N., Lauridsen, T.G., Larsen, N.A., Mikkelsen, L., et al. (2011) The Effect of Glucose Added to the Dialysis Fluid on Blood Pressure, Vasoactive Hormones and Energy Transfer during Hemodialysis in Chronic Renal Failure. Open Journal of Nephrology, 1, 5-14. http://dx.doi.org/10.4236/ojneph.2011.12002

[33] Docheterman, J.M. and Bulechek, G.M. (2010) Classificação das Intervenções de Enfermagem (NIC). Artmed, Porto Alegre.

[34] Guimarães, G.L., Mendoza, I.Y.Q., Goveia, V.R., Baroni, F.C.A. and Godoy, S.C.B. (2014) Diagnósticos de Enfermagem em Hemodiálise fundamentados na teoria de Horta. REUOL, 8, 3444-3451.

[35] Nunes, F.A., Nunes, S.A., Lorena, Y.G., Novo, N.F., Juliano, Y. and Schnaider, T.B. (2014) Autoestima, depressão e espiritualidade em pacientes portadores de doença renal crônica em tratamento hemodialítico. Revista do Médico Residente, 16, 18-26.

[36] Negritti, C.D., Mesquita, P.G.M. and Baracho, N.C.V. (2014) Perfil Epidemiológico de pacientes renais crônicos em tratamento conservador em um hospital escola do Sul de Minas. Revista Ciências em Saúde, 4, 1-12.

[37] Coutinho, N.P.S., et al. (2010) Qualidade de vida de pacientes renais crônicos em hemodiálise. Revista de Pesquisa em Saúde, 11, 13-17.

[38] Cristóvão, A.F.A.J. (2015) Eficácia das restrições hídrica e dietética em pacientes renais crônicos em hemodiálise. Revista Brasileira de Enfermagem, 68, 842-850. http://dx.doi.org/10.1590/0034-7167.2015680622i

[39] Santana, J.C.B., Fortes, N.M., Monteiro, C.L.A., Carvalho, I.M., Leonardo, L.M.U. and Albuquerque, P.G. (2012) Assistência de enfermagem em um serviço de terapia renal substitutiva: Implicações no processo do cuidar. Enfermagem Revista, 15, 161-178.

[40] Bezerra, M.L.R., Ribeiro, P.R.S., Sousa, A.A., Costa, A.I.S. and Batista, T.S. (2012) Diagnósticos de Enfermagem conforme a Teoria do Autocuidado de Orem para pacientes em Tratamento Hemodialítico. Revista Ciência em Extensão, 8, 60-81.

[41] Brites, R.M.R. and Abreu, A.M.M. (2014) Padrão de consumo de bebidas alcoólicas entre os trabalhadores e perfil socioeconômico. Acta Paulista de Enfermagem, 27, 93-99. http://dx.doi.org/10.1590/1982-0194201400018

[42] Ximenes, S.S.R.F. (2013) Diagnósticos de enfermagem no cuidado clínico a pessoas com hipertensão e doença cardiovascular. Dissertação, Universidade Estadual do Ceará, Fortaleza.

[43] Nepomuceno, F.C.L., Melo Jr., I.M.D., Silva, E.D.A. and Lucena, K.D.T.D. (2014) Religiosidade e qualidade de vida de pacientes com insuficiência renal crônica em hemodiálise. Saúde em Debate, 38, 119-128. 